\title{
Tinjuan Teologis Kepemimpinan Berhati Hamba Menurut Filipi 2:1-11 Bagi Pembentukan Karakter Jemaat
}

\author{
Paulus Kunto Baskoro \\ Sekolah Tinggi Teologi Injili Indonesia - Yogyakarta \\ Email: paulusbaskoro1177@gmail.com
}

\begin{abstract}
Leadership is very important. Leadership will grealty affect all aspects of the movement in God's church. Good leadership will produce an extraornidary movement, but if leadership is not good, it will bring decline in a church. God gives trust to church leaders to bring every church to be more advanced and fruitful for the Kingdom of God. Leadership also affects the character of the congreation. God longs for every congregation in God's church to have a Christ-like character. But the problem that arises in a leadership is when someone gets trusted to lead in a church, tends to be authoritarian and arbitratry. Do not base leadership with a servant's heart. The context of this discussion is focused on the example of Jesus in Philippians 2:1-11 who truly has the character of a servant's heart ministry in the world. This research uses a descriptive literature method, which is to learn about the Theological Review of Servant Leadership According to Philippians 2:1-11 For Congregational Character Building from the point of view of the truth of God's Word, because the Bible is the standard of life for believers. The aim is that trough this writing, First, servant-hearted leadership becomes the lifestyle of every Christian leader. Second, Christian leaders can impart a good example to every believer according to the example of Jesus. Third, the character of the congregation is getting better. Fourth, God's church grows to the maximum and can produce futher spiritual leaders who have a servant's heart.
\end{abstract}

Keywords: Character; Christian; Congregation; Leadership; Servant Heart.

\begin{abstract}
Abstrak
Kepemimpinan adalah hal yang sangat penting. Kepemimpinan akan sangat mempengaruhi seluruh aspek kegerakan dalam gereja Tuhan. Kepemimpinan yang baik akan menghasilkan sebuah gerakan yang luar biasa, namun jika kepemimpinan tidak baik, maka akan membawa kemunduran dalam sebuah gereja. Tuhan memberikan kepercayaan kepada para pemimpin gereja untuk membawa setiap gereja menjadi makin lebih maju dan berbuah bagi Kerajaan Allah. Kepemimpinan juga memengaruhi karakter jemaat. Tuhan merindukan setiap jemaat yang ada dalam gereja Tuhan memiliki karakter yang seperti Kristus. Namun problem yang muncul dalam dalam sebuah kepemimpinan adalah ketika seseorang mendapat kepercayaan memimpin dalam sebuah gereja, cenderung otoriter dan semena-mena. Tidak mendasarkan kepemimpinan dengan hati hamba. Konteks pembahasan ini difokuskan kepada teladan Yesus dalam Filipi 2:1-11 yang sungguh memiliki karakter hati hamba dalam pelayanan di dunia. Penelitian ini menggunakan metode diskritif literatur, yaitu mempelajari tentang pribadi Tinjauan Teologis Kepemimpinan Berhati Hamba Menurut Filipi 2:1-11 Bagi Pembentukan Karakter Jemaat dari sudut pandang kebenaran
\end{abstract}


Firman Tuhan, sebab Alkitab adalah standart kehidupan orang percaya. Tujuannya supaya lewat penulisan ini yaitu Pertama, kepemimpinan berhati hamba menjadi gaya hidup setiap pemimpin Kristen. Kedua, pemimpin Kristen dapat mengimpartasikan teladan yang baik bagi setiap orang percaya sesuai dengan teladan Yesus. Ketiga, karakter jemaat menjadi lebih baik. Keempat, gereja Tuhan bertumbuh dengan maksimal dan bisa memunculkan pemimpin-pemimpin rohani selanjutnya yang memiliki hati hamba.

Kata-kata kunci : Hati Hamba; Jemaat; Karakter; Kristen; Kepemimpinan.

\section{PENDAHULUAN}

Kepemimpinan menjadi sentral sebuah kegerakan, serta sebuah sikap untuk memengaruhi baik perseorangan maupun kelompok untuk mengerjakan sebuah tujuan (Dharma, 2019). Kegerakan dalam bentuk apapun sangat dipengaruhi dengan kualitas pemimpin. Pemimpin yang menggerakkan kepada hal-hal yang tidak baik, pasti juga efeknya tidak akan baik, namun pemimpin yang menggerakkan kepada sesuatu yang baik, maka akan terjadi sebuah terobosan yang luar biasa. Kepemimpinan selalu memegang tanggung jawab yang jamak seperti yang dinyatakan dalam pendapat Siahaya (Siahaya, 2019). Dalam sebuah gereja, pemimpin juga menjadi figur sentral untuk membawa gereja menjadi serupa dengan Kristus. Sangat berbeda konsep kepemimpinan rohani dan sekuler, sebab semuanya berhubungan dengan tanggung jawab, moral, etika dan sikap serta keteladanan (Saragih, 2019). Pemimpin menjadi wakil Allah untuk membawa setiap jemaat mengalami pertumbuhan dan kedewasaan yang penuh dalam Kristus. Sebab Tuhanlah yang memberikan pemimpinpemimpin dalam gereja dan para pemimpin harus bertanggung jawab kepada Tuhan, Sang pendelegasi kepemimpinan (Ef. 4:11-16). Sebuah fungsi kepemimpinan yang jelas, dimana pemimpin-pemimpin dapat berfungsi sebagai rasul, nabi, gembala, pemberita Injil dan pengajar. Sehingga jemaat makin bertumbuh pada tingkat kedewasaan rohani ke arah Kristus yang adalah Kepala Gereja. Namun tidak bisa dipungkiri banyak problem dalam konteks kepemimpinan seorang pemimpin (Tari et al., 2019 ). Dimana pemimpin-pemimpin yang Tuhan percayakan untuk memimpin gereja-Nya tidak menunaikan tugas sesuai dengan hati Tuhan. Mereka lebih terfokus kepada konteks kepemimpinan karena keturunan, posisi atau jabatan, egosentris, didaktor, sulit menerima nasihat atau masukan, bahkan memimpin menurut kehendaknya pribadi (Rupa', 2008). Bahkan ada pemimpin-pemimpin yang sudah merasa dipercaya menjadi pemimpin, mereka tidak melaksanakan kepemimpinan dengan baik. Kepemimpinan yang sedang terjadi, lebih bersifat cenderung otoriter dan terkadang sulit untuk menerima masukan dari jemaat. Sehingga tanpa disadari setiap sikap yang ditunjukkan dalam kepemimpinan, akhirnya memengaruhi seluruh jemaat. Menjadi jemaat yang juga sulit dibentuk serta sulit menerima masukan. Ini yang dimaksud kepemimpinan yang memengaruhi karakter jemaat. Inilah yang menjadi dampak besar dalam sebuah kegerakan gereja Tuhan. Pemimpin yang berhati hamba akan membentuk karakter jemaat yang juga berhati hamba. Kepemimpinan akan membawa dampak 
yang sangat besar. Kepemimpinan bicara keefektifannya juga dalam menjadi penggerak dalam sebuah organisasi (Mawikere, 2018). Hal-hal inilah yang sangat menyedihkan dalam konteks kepemimpinan gereja.

Kepemimpinan menjadi sentral sebuah kegerakan. Kepemimpinan yang berfungsi akan menjadi motor penggerak seluruh komponen sebuah organisasi. Namun dalam konsep kepemimpinan rohani, Tuhan merindukan, kepemimpinan rohani bukan secara dedaktor, otoriter bahkan semaunya. Namun hati Tuhan, kepemimpinan yang efektif adalah kepemimpinan berhati hamba yang membawa dampak besar membangun karakter jemaat.

Semua pemimpin rohani menyadari bahwa yang ideal dalam konsep kepemimpinan adalah kepemimpian dengan hati hamba. Fokus kepemimpinan berhati hamba dituangkan dalam analisa dari Filipi 1:5-11 yang bersumber kepada Pribadi Yesus. Kepemimpinan bukan bicara tentang status dan struktural, namun bicara tentang fungsi yang makismal dan membuat tim yang ada dalam pimpinannya juga menjadi lebih maksimal. Kepemimpinan yang berhati hamba adalah Pertama, hidup dalam kasih yang tulus; Kedua, kesehatian dalam visi, Ketiga, fokus kepada kepentingan bersama; Keempat, hati hamba yang murni; Kelima, ketaatan yang mutlak. Ketika pemimpin melaksanakan kepemimpinan dengan penuh dedikasi hati hamba seperti yang nyata dalam 5 karakteristik di atas, maka jemaat yang ada dalam bimbingannya juga akan memiliki karakter yang sama dengan pemimpinnya. Sehingga seluruh kegerakan gereja terjadi dengan dahsyat, baik dalam kekeluargaan, berjemaat, program-program dan kegerakan penginjilan serta pemuridan di gereja lokal. Dan kiranya lewat penulisan ini ada banyak pemimpin menyadari arti sebuah kepemimpinan dan juga menduplikasi sebuah kepemimpinan kepada generasi pemimpin selanjutnya yang memiliki hati hamba.

Beranjak dari beberapa contoh dalam kepemimpinan Kristen seperti kepemimpinan Musa, kepemimpinan Yosua, kepemimpinan Daud, maka kiranya lewat pemahaman saat ini akan disajikan sebuah teladan kepemimpinan yang sesuai kebenaran Firman Tuhan dari Filipi 2:1-11 yang merujuk kepada pribadi Yesus. Yesus sebagai pemimpin sejati yang tidak menghalalkan segala cara untuk memimpin murid-murid-Nya secara khusus dan orang percaya secara umum, meskipun Dia adalah Tuhan. Hati hamba menjadi dasar konsep kepemimpinan yang sejati dalam kekristenan. Sebab pemimpin harus melewati pembentukan proses (S. Zaluchu, 2018). Ketika setiap pemimpin Kristen menerapkan prinsip-prinsip kepemimpinan dengan hati hamba, maka akan terjadi pembentukan karakter jemaat yang juga memiliki hati hamba dalam pelayanan, kehidupan sehari-hari dan juga keluarga. Otomatis ketika kepemimpinan dengan hati hamba menjadi gaya hidup setiap pemimpin gereja, maka seluruh jemaat akan mengalami sebuah terobosan hidup yang luar biasa. Ini adalah sebuah pendekatan kepemimpinan yang sangat baik, sebab pemimpin yang efektif dalam pendekatan, maka efektif dalam pendelegasian (Ghufron, 2020).

Berkaitan dengan topik tinjauan Teologis kepemimpinan Berhati Hamba Menurut Filipi 2:1-11 Bagi Pembentukan Karakter Jemaat juga pernah diteliti oleh Bimo Setyo Utomo dengan penelitian Karakteristik Kepemimpinan Hamba Yesus Kristus menurut Filipi 2:5-8 
(Utomo, 2020). Kesimpulan dari penelitian tersebut adalah bahwa pemimpin adalah seorang hamba atau pelayan, sehingga kepemimpinan sama dengan sebuah pelayanan, bukan kekuasaan. Sri Wahyuni melakukan penelitian serupa dalam artikel berjudul Studi Eksplanatori dan Konfirmatori tentang Kepemimpinan Hamba Berdasarkan Filipi 2: 5-11 di Kalangan Hamba-hamba Tuhan Persekutuan Doa Nazaret SukoharjoWonogiri (Wahyuni, 2018). Dengan kesimpulan bahwa Dalam kepemimpinan hamba hal yang primer bukanlah tugas memimpin, tetapi kesigapan pemimpin dalam melayani dengan segala kerelaan sebagai hamba. Pokok utama bagi seorang pemimpin kehambaan adalah memuliakan Allah dalam hal apapun. Berdasarkan kedua penelitian tersebut masih ada hal-hal yang belum diteliti yaitu tentang Kepemimpinan Berhati Hamba Menurut Filipi 2:1-11 Bagi Pembentukan Karakter Jemaat. Oleh sebab itu artikel ini akan meneliti dan membahas tentang pembentukan karakter jemaat sebagai topik yang akan dideskripsikan.

\section{METODE}

Penelitian ini menggunakan metode kualitatif deskriptif (S. E. Zaluchu, 2020) yaitu mempelajari tentang pribadi Tinjauan Teologis Kepemimpinan Berhati Hamba Menurut Filipi 2:1-11 Bagi Pembentukan Karakter Jemaat dari sudut pandang kebenaran Firman Tuhan, sebab Alkitab adalah standart kehidupan orang percaya. Penulis menggali kebenaran-kebenaran secara studi teologis secara umum dari nas Filipi 2:1-11. Dengan didukung fakta sejarah dengan penelitian studi literatur atau studi pustaka untuk memperkokoh sebuah pemahaman tentang kepemimpinan berhati hamba (Baskoro, 2020a). Dan pemahaman ini akan diimplementasikan bagi orang percaya serta gereja Tuhan, sehingga memiliki dasar teologi yang kokoh, serta iman kepada Yesus lebih kokoh (Ka'pan, 2007).

\section{PEMBAHASAN}

\section{Landasan Nas Filipi 2:1-11}

Berbicara tentang nas Filipi 2:1-11 akan melihat sudut sejarah Surat Filipi, baik dari diri penulis, latar belakang, waktu penulisan dan temanya. Hal ini penting untuk menjadi sebuah acuan memahami konsep yang dibangun tentang kepemimpinan berhati hamba (Marbun, 2020). Surat Filipi merupakan surat yang menarik menjadi perenungan sebab surat ini adalah salah satu surat yang ada dalam Perjanjian Baru yang merupakan surat kiriman Rasul Paulus untuk jemaat yang ada di Filipi. Surat Filipi memiliki kesejajaran dalam pengiriman, yaitu kepada Surat Efesus, Kolose dan Filemon, semua surat-surat ini ditulis Rasul Paulus ketika dipenjara karena memberitakan Injil. Surat Filipi secara garis besar, Paulus sedang bersyukur melihat kehidupan iman jemaat yang bertumbuh dan pesan Paulus supaya mereka tetap bersukacita dalam segala hal meskipun mengalami ada banyak tantangan dan persoalan serta pesan keselamatan yang kuat bagi orang percaya (Surif, 2020). Sebab tidak bisa dipungkiri, masa itu, jemaat-jemaat atau orang percaya menghadapi tantangan, baik dari orang-orang Yahudi maupun tekanan dari pemerintah Romawi. Jemaat Filipi adalah jemaat yang terbukti punya daya juang untuk terus mengikut Yesus dan tetap rendah hati. Jemaat Filipi bertumbuh dalam daerah atau kota yang memiliki arti "mata air" dalam bahasa Yunani yaitu 
"krene." Nama kota ini berasal dari nama raja Makedonia Filipus II yang berhasil mengalahkan kota ini di tahun 360 - 365 SM (Alkitab Penuntun Hidup Berkelimpahan, 2010, p. 1297). Kota Filipi menjadi kota yang pertama kali dikunjungi oleh Rasul Paulus dalam perjalanan misi di daerah Eropa. Jemaat Filipi jemaat yang memang tidak terlalu bagus finansialnya, mereka adalah jemaat-jemaat yang hidup sederhana, namun mereka adalah jemaat yang sangat mengerti arti sebuah pemberian dan membantu serta mendukung perjalanan misi Rasul Paulus (Fil. 1:27-30; 2:21). Jemaat ini dirintis Rasul Paulus bersama rekan sekerjanya Lukas, Silas dan Timotius, sekitar tahun 49-50 M. Jemaat ini berdiri dari sebuah visi penglihatan yang diterima Paulus ketika di Troas (Kis. 16:9-40) (Alkitab Hidup Berkelimpahan Life Application Study Bible, 2016). Jemaat Filipi adalah jemaat Kristen yang terdiri dari orangorang bukan Yahudi (Kis. 16:33b) dan orang-orang Yahudi yang sudah menjadi percaya Yesus (Kis. 16:14). Dari hubungan yang begitu luar biasa dengan jemaat Filipi jelas sekali dinyatakan bahwa Surat Filipi ditulis sendiri oleh Rasul Paulus dalam penjara (Fil. 1:7, 14, 17). Dan kurun waktu penulisan surat Filipi di tahun $62 \mathrm{M}$. Fokus tujuan penulisan Surat Filipi adalah supaya jemaat menjadi pribadi yang kuat berdiri dan selalu sukacita menghadapi tantangan apapun dalam proses mengikut Yesus (Stamps, 2000). Kristus merupakan sentral pembahasan dalam Surat Filipi (Soryadi \& Hermanto, 2019).

Jadi secara historis dari Filipi 2:111 sedang mau memaparkan bahwa penulis melihat ada hubungan secara konteks Pribadi Yesus yang rela memberikan hidupnya sebagai ganti dosa dan berkorban bagi seluruh umat manusia.
Ini adalah konsep hati hamba yang bisa diangkat. Kesejajaran yang terjadi adalah Yesus yang adalah Tuhan rela turun ke dunia, menjadi teladan bagi setiap pemimpin Kristen untuk rela melayani dengan hati hamba. Sehingga dengan konsep ini jemaat Filipi menjadi jemaat yang suka memberi, hidup mau berkorban dan setia dalam penderitaan.

\section{Dasar Pemahaman Umum Karakter Berhati Hamba Menurut Filipi 2:1-11}

Filipi 2:1-11 menjadi sebuah acuan untuk dapat memahami sebuah pelayanan dengan hati hamba. Ini adalah karakter yang sangat ideal dalam melayani Yesus. Yesus sendiri datang ke dunia bukan untuk dilayani, namun untuk melayani (Mark. 10:45). Keteladanan Pribadi Yesus harus menjadi keteladanan setiap orang percaya. Terutama dalam konteks ini menurut Rumahlatu, pemimpin Kristen yang terbaik adalah pemimpin-pemimpin Kristen dapat memberikan keteladanan untuk mau melayani (Rumahlatu, 2017). Dimana pemimpin hadir dengan konsep melayani dan bukan untuk dilayani. Ini adalah salah satu prinsip hati hamba yang Yesus teladankan dalam Filipi 2:1-11. Yesus hadir dengan segala kerendahan hatinya, yaitu merendahkan diri serendahrendahnya menjadi manusia untuk menebus dosa. Jangan pernah berharap menghasilkan karakter jemaat yang serupa dengan Kristus, jika pemimpinnya tidak memiliki karakter Kristus. Lewat Surat Filipi 2:1-11 ada beberapa hal yang merupakan standart pelayanan kepemimpinan Kristen yang berhati hamba dan ini merupakan sebuah kesatuan yang tidak dapat dipisahkan. 
Penghiburan dalam Kasih (ay. 1)

Jemaat Filipi adalah jemaat yang selalu hidup dalam sebuah kekeluargaan yang luar biasa. Filipi 2:1, "Jadi karena dalam Kristus ada nasihat, ada penghiburan kasih, ada persekutuan Roh, ada kasih mesra dan belas kasihan." Meskipun dalam bertumbuh dalam iman yang penuh banyak tantangan, jemaat ini adalah jemaat yang selalu saling membangun dan mensupport serta memberikan bantuan dengan penuh sukacita. Tantangan yang datang tidak membuat mereka menjadi patah semangat dalam mengiring Yesus. Sehingga penghiburan dalam kasih menjadi bagian terpenting untuk Rasul Paulus pesankan dalam nasihatnya kepada jemaat Filipi. Sebagai pemimpin rohani, Rasul Paulus mengingatkan bahwa mereka harus terus membangun sebuah kekuatan iman untuk saling menghibur dan menjadi pelayanpelayan yang menyenangkan hati Tuhan (Kusradi, 2020). Menghibur artinya memberikan dukungan kepada seseorang. Penghiburan dalam kasih akan memberikan semangat yang baru. Ketika penghiburan didasarkan atas sebuah kasih, pastilah tidak ada terjadi pilih kasih.

\section{Selalu dalam Persekutuan Roh (ay. 1)}

Sukacita yang luar biasa, juga dirasakan Paulus ketika melihat jemaat Filipi. Mereka adalah jemaat yang militant serta setia di dalam Yesus. Namun dirasa perlu untuk Rasul Paulus mengingatkan jemaat Filipi, supaya mereka tetap setia dalam persekutuan Roh. Filipi 2:1, "Jadi karena dalam Kristus ada nasihat, ada penghiburan kasih, ada persekutuan Roh, ada kasih mesra dan belas kasihan."

Persekutuan dalam Roh inilah yang membuat jemaat Filipi akan senantiasa bertahan dan makin kuat menghadapi segala tantangan bahkan bersatu padu membawa Injil Kristus kepada siapapun.
Hubungan antara Roh Kudus dan orang percaya (Harefa, 2020). Persekutuan bicara tentang sebuah tindakan perkumpulan yang dilaksanakan untuk saling menguatkan. Inti kekristenan yang sejati adalah selalu hidup dalam persekutuan-persekutuan dan ini adalah inti gereja mula-mula sehingga berkembang dengan dahsyat dalam Kisah Para Rasul (Baskoro, 2020b). Dengan persekutuan dalam Roh yang kuat akan menjadi lebih bersatu. Paulus sebagai pemimpin, sadar bahwa persekutuan merupakan kunci kekuatan untuk Injil tetap diberitakan. Pemimpin yang berhati hamba adalah senantiasa membangun kehidupan rohani dalam persekutuan Roh yang indah. Sebab Kepemimpinan yang sesungguhnya dimulai dari diri pribadi seorang pemimpin dengan hati seorang hamba, kemudian dinyatakan keluar untuk melayani orang lain (Suhadi \& Arifianto, 2020).

\section{Ada Kasih Mesra (ay. 1)}

Kekuatan sebuah hubungan adalah kasih mesra. Semuanya dimulai dari betapa kasihnya Rasul Paulus kepada jemaat Filipi sehingga jemaat Filipi menjadi jemaat yang juga memiliki hubungan kasih mesra. Filipi 2:1, "Jadi karena dalam Kristus ada nasihat, ada penghiburan kasih, ada persekutuan Roh, ada kasih mesra dan belas kasihan."Hubungan kasih mesra ini didasarkan kepada kasih Kristus yang telah mengikat mereka karena pemberitaan Injil. Kasih mesra membuat sebuah hubungan makin indah. Pemimpin yang memiliki karakter mengasihi dengan sungguh, dipastikan akan menghasilkan pertumbuhan karakter jemaat yang juga saling mengasihi. Kasih mesra menjadi dasar sebuah kekuatan gereja, serta menjadi berkat bagi bangsa (Arifianto \& Stevanus, 2020). 
Penuh Belas Kasihan (ay. 1)

Dasar belas kasihan Kristus menjadi kunci yang sangat penting dalam sebuah gereja. Filipi 2:1, "Jadi karena dalam Kristus ada nasihat, ada penghiburan kasih, ada persekutuan Roh, ada kasih mesra dan belas kasihan." Sebab belas kasihan Kristus tidak bersumber kepada perasaan, namun kepada kasih yang muncul karena jiwa-jiwa yang harus diselamatkan (Yen, 2019). Belas kasihan yang muncul adalah belas kasihan pada jiwa-jiwa yang terhilang dan perhatian kepada kehidupan orang percaya. Bagi Rasul Paulus ketika jemaat Filipi hidup dengan belas kasihan Kristus, maka yang yang terjadi mereka akan militant dalam mencari jiwa dan membawanya kepada Kristus, sebab saling mensupport juga dalam kehidupan sehari-hari. Karakter inilah yang harus dikembangkan oleh orang percaya, terutama pemimpin Kristus, sehingga seperti hatinya Tuhan melihat manusia, demikianlah orang percaya melihat setiap jiwa-jiwa dengan penuh belas kasihan untuk diselamatkan.

Sehati Sepikir, Satu Kasih, Satu Jiwa, Satu Tujuan (ay. 2)

Dasar karakter yang kadang sulit sekali terjadi adalah sehati sepikir, satu kasih, satu jiwa dan satu tujuan. Filipi 2:2 "karena itu sempurnakanlah sukacitaku dengan ini: hendaklah kamu sehati sepikir, dalam satu kasih, satu jiwa, satu tujuan."

Ini membutuhkan kerendahan hati dan kebesaran hati untuk melihat sisi yang lain dalam sebuah pandangan namun tetap bisa menerima dengan sukacita. Sehati sepikir berbicara tentang meskipun mungkin ada perbedaan pendapat namun dengan semangat yang sama bisa meraih dan mengoptimalkan pandangan yang sudah disepakati (Sinukaban, 2018). Sebab mau tidak mau dalam kehidupan berjemaat, jemaat Filipi memiliki cara pandangan yang kadang berbeda satu dengan yang lain dalam memberikan penyelesaian sebuah pandangan. Rasul Paulus mengingatkan untuk mereka sehati dan sepikir. Artinya bukan berarti tidak boleh memberikan pandangan pemikiran dalam sebuah proses permasalahan yang timbul. Namun jika sudah disepakati dengan pertimbangan-pertimbangan yang matang, maka seluruh jemaat harus mendukung. Sebab fokusnya adalah kasih Kristus. Bukan kasih karena kesamaan posisi jabatan bahkan beberapa hal yang berhubungan dengan keduniawian. Kasih yang menjadi dasarnya adalah kasih Kristus yang menerima orang percaya apa adanya (Alexander, 2009, p. 127). Satu kasih artinya Kristus yang telah mempersatukan, demikianlah kiranya bisa hidup saling menerima satu sama lain tanpa membeda-bedakan unsur harta, jabatan bahkan kelebihan dan kelemahan. Kasih merupakan pengikat yang mempersatukan dan menyempurnakan. Pemimpin yang penuh kasih akan membawa jemaat menjadi pribadi yang penuh kasih. Dalam jiwa ada pikiran, perasaan dan kehendak. Rasul Paulus mengingatkan kepada jemaat Filipi untuk dalam satu jiwa. Pikiran, perasaan dan kehendak menjadi satu dalam Kristus. Namun apa saja yang terjadi, seluruh potensi kehidupan harus fokus kepada hal yang sudah disepakati tanpa menghakimi satu sama lain dan bisa menerima dengan sukacita. Sebab Tuhan akan memberkati orang percaya yang hidupnya sehati, seperti doa Tuhan Yesus dalam Yohanes 17, supaya murid-murid-Nya satu, sama seperti Bapa dan Yesus adalah satu. Tuhan pasti memiliki tujuan besar atas gereja- 
Nya. Sebab Kepala gereja adalah Kristus, jemaat adalah tubuh. Yesus sebagai Kepala Gereja pasti memiliki tujuan yang sangat jelas bagi gereja-Nya (Wiersbe \& Sugden, 2003). Gereja Tuhan yang didirikan bukan hanya untuk satu atau dua tahun saja, namun sampai selama-lamanya. Bukti kesehatian bukan saja pikiran, perasaan dan kehendak namun juga tujuan gereja Tuhan yang sudah didoakan.

Tidak Mencari Kepentingan Sendiri dan yang Sia-Sia (ay. 3)

Rasul Paulus mengingatkan jemaat Filipi untuk hidup dalam berjemaat untuk tidak mencari kepentingan diri sendiri, sebab mencari kepentingan diri sendiri adalah hal yang sia-sia. Filipi 2:3, "dengan tidak mencari kepentingan sendiri atau puji-pujian yang sia-sia. Sebaliknya hendaklah dengan rendah hati yang seorang menganggap yang lain lebih utama dari pada dirinya sendiri;" Bahkan pemimpin-pemimpin yang ada dalam jemaat juga harus hidup berfokus kepada kepentingan orang lain dan bukan berfokus kepada kepentingan pribadi. Kepentingan pribadi akan menimbulkan gejolak dan perselisihan. Namun mengutamakan kepentingan orang lain adalah cerminan karakter Kristus yang berfokus kepada jiwa-jiwa yang diselamatkan. Ini esensi dasar kehidupan karakter berhati hamba. Pemimpin yang berfokus kepada kepentingan bersama akan membawa sebuah terobosan yang dashyat dalam gereja Tuhan. Ini adalah sikap dengan rendah hati, menganggap yang lain lebih utama dari yang lain. Kerendahan hati adalah wujud sikap hati hamba yang paling mendasar (Wiseman, 1994).
Menaruh Pikiran dan Perasaan yang Terdapat dalam Kristus (ay. 5)

Sentral kehidupan Kristen adalah pikiran dan perasaan yang terdapat dalam Kristus. Filipi 2:5, "Hendaklah kamu dalam hidupmu bersama, menaruh pikiran dan perasaan yang terdapat juga dalam Kristus Yesus," Dalam bagian ini Rasul Paulus mengingatkan jemaat Filipi, bahwa dalam apapun yang terjadi, seharusnya berfokus kepada pikiran dan perasaan yang terdapat dalam Kristus. Pikiran dan perasaan Kristus adalah jiwa-jiwa (Sanders, 1993). Jiwa-jiwa menjadi fokus kehadiran Yesus ke dunia dan mati di kayu salib. Banyak orang selalu tertuju kepada pikiran dan perasaan pribadi. Padahal pikiran dan perasaan pribadi itu beragam. Keberagaman yang bertujuan pada kepentingan diri sendiri tidak akan membawa dampak yang besar bagi Kerajaan Allah. Paulus dalam bagian ini menyadarkan bahwa hidup jemaat dan pemimpin gereja harus bersumber kepada pikiran dan perasaan yang terdapat dalam Kristus.

Tidak Ada Hak Milik yang harus Dipertahankan (ay. 6-7)

Yesus datang ke dunia dengan sebuah misi bagi penyelamatan manusia. Yesus adalah Tuhan, Pencipta alam semesta dan yang berdaulat atas seluruh kehidupan manusia. Yesus rela meninggalkan sorga dengan segala milik yang harus dipertahankan, turun ke dunia untuk menjadi manusia. Filipi 2:6-7, “yang walaupun dalam rupa Allah, tidak menganggap kesetaraan dengan Allah itu sebagai milik yang harus dipertahankan, melainkan telah mengosongkan diri-Nya sendiri, dan mengambil rupa seorang hamba, dan menjadi sama dengan manusia." Kesetaraan dengan Allah yang 
tidak perlu dipertahankan. Pribadi yang menjadi tebusan bagi semua orang percaya. Ini adalah teladan hati hamba yang Yesus miliki. Sebetulnya berkaca dari pemahaman ini, tidak ada apapun yang orang percaya harus pertahankan. Yesus yang adalah Allah, rela menjadi hamba. Semua ini dilakukan Yesus, karena manusia berharga dan siap menjadi tebusan bagi dosa umat manusia. Hati hamba adalah bicara tentang konsep terbesar dalam kehidupan orang percaya. Yesus berkata kepada murid-murid-Nya, barangsiapa yang ingin menjadi besar, harus menjadi yang terkecil. Bahkan Yesus memberikan teladan, bahwa kedatanganNya bukan untuk dilayani melainkan untuk melayani. Hati hamba selalu berbicara tentang buat siapa hidup ini ada dan tidak lagi tertuju kepada diri sendiri. Rasul Paulus menghendaki jemaat dan para pemimpin gereja untuk berfokus hidup dengan hati hamba. Roh Kudus akan memberikan kemampuan bagi setiap orang percaya untuk memiliki karakter hati hamba seperti Yesus (Hocking, 2009). Ini adalah panggilan yang tertinggi dan harga keselamatan adalah hati hamba Yesus yang harus menjadi teladan setiap orang percaya terutama pemimpin gereja.

\section{Merendahkan Diri (ay. 8)}

Yesus merendahkan diri serendahrendahnya menjadi manusia. Filipi 2:8, "Dan dalam keadaan sebagai manusia, Ia telah merendahkan diri-Nya dan taat sampai mati, bahkan sampai mati di kayu salib." Yesus menjadi manusia dengan tujuan besar manusia diselamatkan. Keselamatan menjadi sentral pesan dan kehadiran Yesus di dalam dunia. Yesus merendahkan diri artinya Dia rela mengalami hal-hal yang seharusnya tidak perlu Yesus alami. Banyak hal yang nyaman ditinggalkan Yesus ketika Yesus harus merendahkan diri serendahrendahnya menjadi manusia. Baik itu sorga, kemuliaan dan kejayaan. Hal ini menunjukkan bahwa manusia sangat berharga dihadapan Yesus, terbukti Yesus merendahkan diri menjadi manusia. Yesus yang tidak berdosa disebut berdoa karena orang percaya tebusan-Nya. Dia yang tidak terkutuk disebut terkutuk karena dosa umat manusia. Rasul Paulus menyatakan ini dalam suratnya menjadi sebuah acuan salah satu karakter yang harus dimiliki oleh pemimpin rohani, yaitu rendah hati (Octavianus, 2000, p. 98). Terlebih kepemimpinan begitu erat kaitannya dengan kepemimpinan yang melayani (Simon \& Poluan, 2021).

\section{Taat dengan Sungguh (ay. 8)}

Ketaatan Yesus sampai di kayu salib menjadi harga yang harus dibayar demi sebuah karya keselamatan. Filipi 2:8, "Dan dalam keadaan sebagai manusia, Ia telah merendahkan diri-Nya dan taat sampai mati, bahkan sampai mati di kayu salib." Tanpa sebuah ketaatan, tidak mungkin keselamatan akan menjadi bagian umat manusia. Rasul Paulus mau mengingatkan jemaat Filipi atau para pemimpin Filipi untuk mereka sadar bahwa kunci segala-galanya adalah ketaatan. Setia dalam proses tanpa protes. Ketaatan artinya melakukan secara tepat yang diperintahkan tanpa hati yang bersungut-sungut. Ketaatan yang mutlak akan membawa sebuah karya besar. Yesus sudah buktikan itu (Damazio, 1993). Harapan besar Rasul Paulus adalah seluruh jemaat Filipi menjadi pribadi-pribadi yang taat akan kebenaran Firman Tuhan. Ketaatan akan kebenaran Firman Tuhan menjadi tolak ukur kehidupan yang berhati hamba. Hati hamba pasti tidak akan 
berontak dan selalu dengan ucapan syukur menerima setiap perintah yang ada. Ini menunjukkan sebuah karakter ketundukan kepada otoritas diatasnya.

\section{Prinsip-Prinsip Teologis Karakter Kepemimpinan Berhati Hamba dalam Pembentukan Karakter Jemaat}

Berdasarkan penelaahan Filipi 2:111 dapat diambil sebuah kesimpulan tentang prinsip-prinsip teologis kepemimpinan berhati hamba dalam pembentukan karakter jemaat. Sentral teladan adalah Pribadi Yesus, yang adalah Allah rela menjadi manusia untuk menyelesaikan karya penyelamatan dari konteks Filipi 2:5-11. Jadi pemimpin yang berhati hamba akan membawa dampak yang besar dalam kehidupan jemaat. Teladan yang dihasilkan para pemimpin harus terjaga dengan baik secara konsisten (Junetri \& Widjaya, 2020). Jemaat akan merasakan sebuah terobosan yang luar biasa dalam kehidupan dan banyak hal-hal baru yang akan terjadi di gereja Tuhan, sehingga dengan kepemimpinan terjadi transformasi yang dahsyat (Natonis, 2020).

\section{Hidup dalam Kasih yang Tulus}

Prinsip teologi karakter

kepemimpinan berhati hamba dalam pembentukan karakter jemaat terlihat ketika dalam kepemimpinan mengembangkan sikap hidup dalam kasih yang tulus. Kasih Kristus menjadi dasar dalam membangun sebuah hidup kepemimpinan. Apapun yang dilakukan jika dilakukan dengan kasih akan membawa sebuah kekuatan yang luar biasa. Kasih yang tulus menjadi sentral karakter yang harus dikembangkan dan gembala yang menjadi teladan (Santo \& Simanjuntak, 2019). Seperti juga imam- imam dalam Perjanjian Lama juga menjadi teladan bagi bangsa Israel (Baskoro, 2020a). Sebab percayalah ketika kepemimpinan dibangun dengan kasih yang tulus, maka akan membentuk jemaat yang digembalakan juga memiliki kehidupan dalam kasih yang tulus. Jemaat akan melihat teladan yang diatasnya. 1 Korintus 13:13, "Demikianlah tinggal ketiga hal ini, yaitu iman, pengharapan dan kasih, dan yang paling besar di antaranya ialah kasih." Iman akan selesai, pengharapan akan selesai, namun kasih akan selalu ada sampai selama-lamanya. Bahkan sorga penuh kasih. Kepemimpinan dengan kasih yang tulus akan membawa kualitas karakter jemaat yang juga memiliki kasih yang tulus sebagai wujud hati hamba. Kepemimpinan berhati hamba dengan kasih yang tulus yaitu, Pertama, selalu mengutamakan sentuhan yang menyejukkan bagi seluruh jemaat yang dipimpinnya. Kedua, tidak memaksakan kehendak tentang sebuah pendapat dan lebih memilih pendapat bersama. Ketiga, fokus kepada jiwa-jiwa yang harus mengalami pemulihan. Keempat, membangun sebuah rasa kekeluargaan dalam kepemimpinan. Kelima, memberikan penghiburan yang membangkitkan semangat baru bagi seluruh jemaat.

\section{Kesehatian dalam Visi}

Visi akan tercapai ketika setiap orang percaya menjadi satu. Tuhan memberikan visinya kepada pemimpinpemimpin gereja. Visi adalah kemampuan melihat ke depan apa yang Tuhan nyatakan bagi gereja-Nya. Tuhan tidak pernah salah memberikan visinya dan memilih pemimpin-pemimpin gereja. Namun yang perlu dikembangkan adalah bagaimana pencapaian dalam visi yang telah Tuhan 
taruh. Ini sebuah hal yang penting. Sebab dimana ada gereja berdiri, pasti ada rencana Tuhan yang luar biasa. Pemimpin gereja harus bisa menterjemahkan visi Tuhan yang telah diberikan. Sehati, sepikir, satu jiwa, satu kasih dan satu tujuan harus menjadi tekad bersama untuk mencapai visi yang telah Tuhan taruh di hati pemimpin. Pemimpin yang berhati hamba, harus bersama membangun kesehatian bersama jemaat untuk mewujudkan visi dari Tuhan. Hal ini menjadi dasar sebuah pencapaian yang luar biasa. Pemimpin harus bisa dengan rendah hati bersama jemaat bergandengan tangan membangun gereja Tuhan dan terus membawa dalam doa (Wagner, 1999, p. 19). Pemimpin yang berhati hamba untuk membangun kesehatian dalam visi dalam membangun karakter jemaat yaitu Pertama, melihat visi yang Tuhan taruh sebagai bagian untuk membangun gereja Tuhan secara bersama. Kedua, melihat bahwa Tuhan sangat mengasihi gerejaNya. Ketiga, jemaat menjadi pribadi yang terlibat dalam seluruh aspek bidang pelayanan demi keterwujudan visi yang telah Tuhan taruh. Keempat, mendoakan secara bersama visi yang telah Tuhan nyatakan bagi gereja-Nya Kelima, mewujudkan dalam sebuah kegerakan bersama, pemimpin yang sehati dalam visi adalah pemimpin yang juga bersama jemaat ikut terjun menghidupi visi itu.

\section{Fokus kepada Kepentingan Bersama}

Pemimpin yang dirindukan Tuhan adalah melihat pemimpin-pemimpin yang memimpin bukan untuk kepentingan diri sendiri. Namun segala yang dilakukannya demi kepentingan bersama. Ini adalah sebuah hubungan kasih mesra dalam kekeluargaan dan komunitas yang baik (Krik, 2010, p. 177). Membangun sebuah kepemimpinan dengan kekeluargaan. Banyak pemimpin yang memimpin namun berfokus kepada kepentingan diri sendiri. Yesus harus menjadi sentral dalam kepemimpinan Kristen. Pemimpin yang egois akan menghasilkan jemaat yang egois. Yesus mengajarkan hendaklah dalam hidup bersama menaruh pikiran dan perasaan yang terdapat dalam Kristus, yaitu selalu tertuju kepada keselamatan umat manusia. Bahkan pemimpin yang sejati adalah pemimpin yang meskipun tidak diperdulikan oleh siapapun, tetap berjalan dan menunaikan semua tugas tanggung jawab demi seluruh jemaat, bahkan sampai titik darah penghabisan serta menjadi garam dan terang dunia (Arifianto et al., 2020). Pemimpin yang berhati hamba yang berfokus kepada kepentingan bersama dalam membangun karakter jemaat yaitu Pertama, selalu mengutamakan kepentingan bersama dalam Kristus. Kedua, rela untuk memnberikan support dan semangat kepada yang lain. Ketiga, tidak mempertahankan pendapat pribadi dan menghargai pendapat yang jauh lebih baik untuk dilakukan bersama-sama. Keempat, mengatur dengan baik segala hal yang akan dilakukan dalam pelayanan demi kebersamaan. Kelima, tidak membandingbandingkan dan membeda-bedakan setiap jemaat yang dipercayakan dan berusaha dengan maksimal untuk membuat seluruh jemaat makin dewasa dalam Kristus.

\section{Hati Hamba yang Murni}

Pribadi yang memiliki hati hamba adalah pribadi yang dicari Tuhan dalam melanjutkan karya gereja-Nya di dalam dunia. Inilah yang menjadi kunci dalam segala kegerakan gereja Tuhan. Kepemimpinan yang berhati hamba harus menjadi karakter utama seperti Yesus yang 
rela meninggalkan sorga dan menjadi sama seperti manusia. Melepaskan seluruh atribut sorga, Dia Allah yang menjadi manusia. Sebuah teladan yang luar biasa, sebab ini adalah awal misi Yesus ke dalam dunia, menebus dosa seluruh umat manusia. Tanpa konsep ini, pengorbanan tidak mungkin akan terjadi (Gea, 2020). Hati hamba ini tidak bicara tentang posisi atau struktur. Tetapi ini berbicara tentang hati. Hati yang dibentuk dan diproses menjadi serupa dengan Kristus. Posisi atau struktur boleh tinggi, namun dalam pelayanan dengan sikap hati hamba dan ini adalah sebuah seni mendengarkan (Bruce Lason, Paul Anderson, 1996, p. 107). Kepemimpinan dengan hati hamba yang murni akan membawa dampak yang sangat luar biasa membentuk dan berimpartasi dalam kehidupan jemaat, serta memberikan nilai yang berbeda (Santo, 2017). Pemimpin yang berhati hamba secara murni dalam membangun karakter jemaat yaitu Pertama, pribadi setia dalam proses Tuhan. Kedua, pribadi yang rendah hati. Ketiga, pribadi yang siap menerima nasihat dan siap bertumbuh dalam kedewasaan penuh dalam Kristus. Keempat, menjadi pribadi yang siap bekerjasama, satu tujuan demi kemuliaan Allah. Kelima, berani membayar harga (S. E. Zaluchu, 2004, p. 67).

\section{Ketaatan yang Mutlak}

Kristus sudah membuktikan dan menjadi teladan yang sempurna dalam konteks ketaatan. Pemimpin yang berhati hamba dan memberikan dampak besar dalam membangun karakter yang sesuai dengan karakter Kristus adalah ketaatan. Ketaatan Yesus membawa sebuah karya penebusan. Bukti ketaatan selalu nyata dan proses tidak pernah membohongi hasil. Ketika kepemimpinan dibangun dengan unsur ketaatan maka akan menghasilkan jemaat yang memiliki karakter yang juga memiliki ketaatan yang mutlak. Ketaatan kepada Firman Tuhan menjadi bagian terpenting (Djadi, 2012). Memang berbicara ketaatan tidak semudah yang dibayangkan, sebab ini harus benar-benar menyalibkan daging. Namun ketaatan akan membawa orang mencapai puncak hidup dengan kekuatan Tuhan. Pemimpin yang berhati hamba dengan ketaatan yang mutlak dalam membangun karakter jemaat yaitu Pertama, keoptimalan dalam kehidupan dan pelayanan. Kedua, menjadikan hidup memiliki karakter yang kuat dalam ketundukan kepada otoritas diatasnya. Ketiga, membangun sinergi yang kuat dalam kerjasama. Keempat, hidup menjadi saksi, karena selalu mengerjakan apa yang menjadi inti kebenaran Firman Tuhan. Kelima, mengalami berkat yang bekelimpahan dari Allah.

\section{KESIMPULAN}

Kepemimpinan menjadi sentral sebuah kegerakan. Kepemimpinan yang berfungsi akan menjadi motor penggerak seluruh komponen sebuah organisasi. Dalam konteks kepemimpinan rohani, pemimpin menjadi salah satu pemacu sebuah terobosan dalam gereja, lembaga rohani dan juga jemaat. Kepemimpinan memang sebuah struktural. Namun dalam konsep kepemimpinan rohani, Tuhan merindukan, kepemimpinan rohani bukan secara dedaktor, otoriter bahkan semaunya. Namun hati Tuhan, kepemimpinan yang efektif adalah kepemimpinan berhati hamba yang membawa dampak besar membangun karakter jemaat. Sebab apa saja yang pemimpin lakukan menjadi point penting bagi jemaat untuk meneladaninya. 
Seperti Yesus menjadi teladan yang terbaik dalam konsep kepemimpinan. Sebab segala yang dilakukan Yesus selalu mengutamakan jiwa-jiwa. Ini adalah misi terbesar yang luar biasa.

Semua pemimpin rohani menyadari bahwa yang ideal dalam konsep kepemimpinan adalah kepemimpian dengan hati hamba. Fokus kepemimpinan berhati hamba dituangkan dalam analisa dari Filipi 1:5-11 yang bersumber kepada Pribadi Yesus. Kepemimpinan bukan bicara tentang status dan struktural, namun bicara tentang fungsi yang makismal dan membuat tim yang ada dalam pimpinannya juga menjadi lebih maksimal. Kepemimpinan yang berhati hamba adalah Pertama, hidup dalam kasih yang tulus; Kedua, kesehatian dalam visi, Ketiga, fokus kepada kepentingan bersama; Keempat, hati hamba yang murni; Kelima, ketaatan yang mutlak. Ketika pemimpin melaksanakan kepemimpinan dengan penuh dedikasi hati hamba seperti yang nyata dalam 5 karakteristik di atas, maka jemaat yang ada dalam bimbingannya juga akan memiliki karakter yang sama dengan pemimpinnya. Sehingga seluruh kegerakan gereja terjadi dengan dahsyat, baik dalam kekeluarga, berjemaat, program-program dan kegerakan penginjilan serta pemuridan di gereja lokal. Dan kiranya lewat penulisan ini ada banyak pemimpin menyadari arti sebuah kepemimpinan dan juga menduplikasi sebuah kepemimpinan kepada generasi pemimpin selanjutnya yang memiliki hati hamba.

\section{DAFTAR PUSTAKA}

Alexander, D. (2009). Intrik dalam Gereja. Yayasan Andi.

Alkitab Hidup Berkelimpahan Life application Study Bible. (2016). Gandum Mas.
Alkitab Penuntun Hidup Berkelimpahan. (2010). Gandum Mas.

Arifianto, Y. A., \& Stevanus, K. (2020).

Membangun Kerukunan Antarumat Beragama dan Implikasinya bagi Misi Kristen. HUPERETESS: Jurnal Teologi Dan Pendidikan Kristen, 2(1), 39-51. https://doi.org/10.46817/huperetes.v2i 1.44

Arifianto, Y. A., Triposa, R., \& Supriyadi, D. (2020). Menerapkan Matius 5: 13 Tentang Garam Dunia di Tengah Era Disrupsi. Shamayim: Jurnal Teologi Dan Pendidikan Kristiani, 1(1), 92106.

Baskoro, P. K. (2020a). Konsep Imam dan Jabatan Imam pada Masa Intertestamental. Jurnal Teologi Berita Hidup, 3(1), 81-95. https://doi.org/10.38189/jtbh.v3i1.50

Baskoro, P. K. (2020b). Teologi Kitab Kisah Para Rasul dan Sumbangannya dalam Pemahaman Sejarah Keselamatan. Jurnal Teologi (JUTEOLOG), 1(1), 15-35. https://doi.org/10.52489/juteolog.v1i1 .14

Bruce Lason, Paul Anderson, D. S. (1996). Pelayanan Penggembalaan yang Ideal. Gandum Mas.

Damazio, F. (1993). Kepemimpinan yang Sukses. Harvest Publication House.

Dharma, A. (2019). Gaya kepemimpinan yang efektif. Journal of Islamic Management an Bussines, 2(1), 1-8.

Djadi, J. (2012). Spiritual Seorang Pelayan Tuhan. Jurnal Jaffray, 10(1), 110117.

Gea, I. (2020). Kepemimpinan Yesus Teladan Pemimpin Masa Kini. Voice of Wesley: Jurnal Ilmiah Musik Dan Agama, 3(2), 29-40. https://doi.org/10.36972/jvow.v3i2.52

Ghufron, G. (2020). Teori-Teori Kepemimpinan. Fenomena, 19(1), 73-79.

https://doi.org/10.35719/fenomena.v1 9i1.34

Harefa, F. L. (2020). Peranan Kaum Awam Dalam Pelayanan Gereja. SCRIPTA: 
Jurnal Teologi Dan Pelayanan Kontekstual, 5(1), 26-48. https://doi.org/10.47154/scripta.v5i1.4 4

Hocking, D. (2009). Rahasia Keberhasilan Seorang Pemimpin. Yayasan Andi.

Junetri, G., \& Widjaya, Y. A. (2020). Kepemimpinan Guru Kristen: Sebuah Tinjauan Etika Kristen. BIA': Jurnal Teologi Dan Pendidikan Kristen Kontekstual, 3(2), 198-213. https://doi.org/10.34307/b.v3i2.149

Ka'pan, P. (2007). Kebangkitan Yesus Kristus Dasar Iman Kristen. Jurnal Jaffray, $\quad 5(1), \quad 7$. https://doi.org/10.25278/jj71.v5i1.121

Krik, A. (2010). Komunitas yang Diubahkan. Perkantas.

Kusradi, S. W. (2020). Kasih Setia Tuhan Dalam Perjanjian Lama Dan Relevansinya Bagi Orang Percaya Pada Masa Covid-19. SCRIPTA: Jurnal Teologi Dan Pelayanan Kontekstual, 9(1), 53-71. https://doi.org/10.47154/scripta.v9i1.1 12

Marbun, T. (2020). Kajian Biblika Tentang Keselamatan Berdasarkan Kitab Filipi 2:12. BONAFIDE: Jurnal Teologi Dan Pendidikan Kristen, 1(1), 84103.

https://doi.org/10.46558/bonafide.v1i 1.12

Mawikere, M. C. S. (2018). Efektivitas, Efisiensi Dan Kesehatan Hubungan Organisasi Pelayanan Dalam Kepemimpinan Kristen. Evangelikal: Jurnal Teologi Injili Dan Pembinaan Warga Jemaat, 2(1), 50-67. https://doi.org/10.46445/ejti.v2i1.95

Natonis, H. Y. (2020). Kepemimpinan Transformatif Dalam Perspektif Pendidikan Agama Kristen. Voice of Wesley: Jurnal Ilmiah Musik Dan Agama, 3(2), 15-27. https://doi.org/10.36972/jvow.v3i2.48

Octavianus. (2000). Manajemen dan Kepemimpinan Menurut Wahyu Allah. Yayasan Kalam Hidup.

Rumahlatu, J. (2017). Kepemimpinan Spiritual. Lisan Al-Hal, 4(1), 25-50.
Rupa', C. S. (2008). Motivasi Dalam Pelayanan Mempengaruhi Pengajaran dan Perilaku. Jurnal Jaffray, 6(2), 37. https://doi.org/10.25278/jj71.v6i2.105

Sanders, J. O. (1993). Kepemimpinan Rohani. Yayasan Kalam Hidup.

Santo, J. C. (2017). Makna Kesatuan Gereja dalam Efesus 4: 1-16. Jurnal Teologi El-Shadday, 4(1), 1-34. http://stt-elshadday.ac.id/ejournal/index.php/elshadday/article/view/1

Santo, J. C., \& Simanjuntak, D. T. (2019). Pengaruh Keteladanan Hidup Gembala Sidang terhadap Pertumbuhan Gereja. KHARISMATA: Jurnal Teologi Pantekosta. https://doi.org/10.47167/kharis.v2i1.2 3

Saragih, D. R. P. (2019). IMPLEMENTASI KEPEMIMPINAN KRISTEN. Voice of Wesley: Jurnal Ilmiah Musik Dan Agama. https://doi.org/10.36972/jvow.v2i2.27

Siahaya, J. (2019). Kepemimpinan Kristen dalam Pluralitas Indonesia. Jurnal Teruna Bhakti, 1(1), 1. https://doi.org/10.47131/jtb.v1i1.8

Simon, S., \& Poluan, A. (2021). Model Kepemimpinan yang Ideal Dalam Penataan Organisasi Gereja. SHAMAYIM: Jurnal Teologi Dan Pendidikan Kristiani, 1(2), 133-147. https://doi.org/10.51615/sha.v1i2.22

Sinukaban, E. A. (2018). Prinsip Hidup Jemaat Mula-mula dalam Kisah Para Rasul 2:41-47. PNEUSTOS: Jurnal Teologi Pantekosta, 1(1), 43-57.

Soryadi, \& Hermanto, B. (2019). Konsep Tentang Sikap Pelayanan Gembala Sidang dan Keterlibatan Jemaat dalam Pelayanan. Jurnal Teologi Dan Pendidikan Kristen, 1(2), 140-153.

Stamps, D. C. (2000). Alkitab Penuntun Hidup Berkelimpahan. Gandum Mas.

Suhadi, S., \& Arifianto, Y. A. (2020). Pemimpin Kristen Sebagai Agen Perubahan di Era Milenial. Edulead Journal of Christian Education And Leadership, 1(2), 129-147.

Surif, S. (2020). AGUSTUS VERSUS 
KRISTUS DI SURAT FILIPI (BAGIAN 2): Pembacaan AntiImperial terhadap Filipi 2:6-11. Jurnal Amanat Agung, 14(2). https://doi.org/10.47754/jaa.v14i2.358 Tari, E., Mosooli, E. A., \& Tulaka, E. E. (2019). Kepemimpinan Kristen Berdasarkan 1 Timotius 3:1-7. Jurnal Teruna Bhakti, 2(1), 15. https://doi.org/10.47131/jtb.v2i1.22

Utomo, B. S. (2020). Karakteristik Kepemimpinan Hamba Yesus Kristus Menurut Filipi 2: 5-8. DIEGESIS: Jurnal Teologi Kharismatika, 3(2), 107-119.

Wagner, P. (1999). Gereja yang Berdoa. Yayasan Andi.

Wahyuni, S. (2018). Studi Eksplanatori dan Konfirmatori tentang Kepemimpinan Hamba Berdasarkan Filipi 2: 5-11 di Kalangan Hambahamba Tuhan Persekutuan Doa Nazaret Sukoharjo-Wonogiri. Sekolah Tinggi Teologi Kadesi Yogyakarta.

Wiersbe, W. W., \& Sugden, H. F. (2003). Memimpin Gereja Secara Mantap. Lembaga Literatur Baptis.

Wiseman, H. . L. dan N. B. (1994). Pelayanan Allah yang Berjiwa Besar. Yayasan Pekabaran Injil Immanuel.

Yen, E. G. (2019). Tinjauan Ulang Penginjilan Pribadi Dalam Kerangka Amanat Agung Tuhan Yesus Melalui Eksposisi Matius 28:19-20. Jurnal Mahasiswa Teologi Iman, 5(1), 3148.

Zaluchu, S. (2018). Respons Tests of Leadership Menurut Teori Frank Damazio Pada Mahasiswa Pascasarjana Jurusan Kepemimpinan Kristen STT Harvest Semarang. In Jurnal Jaffray (Vol. 16, Issue 2, p. 145).

https://doi.org/10.25278/jj71.v16i2.28 9

Zaluchu, S. E. (2004). Pemimpin Pertumbuhan Gereja. Yayasan Kalam Hidup.

Zaluchu, S. E. (2020). Strategi Penelitian Kualitatif dan Kuantitatif Di Dalam Penelitian Agama. Evangelikal:
Jurnal Teologi Injili Dan Pembinaan Warga Jemaat, 4(1), 28-38. https://doi.org/10.46445/ejti.v4i1.167 